\title{
Characterization of Thiomonas delicata arsenite oxidase expressed in Escherichia coli
}

\author{
Wei Kheng Teoh ${ }^{1} \cdot$ Faezah Mohd Salleh $^{1} \cdot$ Shafinaz Shahir ${ }^{1}$
}

Received: 30 November 2016/Accepted: 20 January 2017/Published online: 30 May 2017

(C) Springer-Verlag Berlin Heidelberg 2017

\begin{abstract}
Microbial arsenite oxidation is an essential biogeochemical process whereby more toxic arsenite is oxidized to the less toxic arsenate. Thiomonas strains represent an important arsenite oxidizer found ubiquitous in acid mine drainage. In the present study, the arsenite oxidase gene (aioBA) was cloned from Thiomonas delicata DSM 16361, expressed heterologously in E. coli and purified to homogeneity. The purified recombinant Aio consisted of two subunits with the respective molecular weights of 91 and $21 \mathrm{kDa}$ according to SDS-PAGE. Aio catalysis was optimum at $\mathrm{pH} 5.5$ and $50-55{ }^{\circ} \mathrm{C}$. Aio exhibited stability under acidic conditions ( $\mathrm{pH} 2.5-6$ ). The $V_{\max }$ and $K_{\mathrm{m}}$ values of the enzyme were found to be $4 \mu \mathrm{mol} \mathrm{min}{ }^{-1}$ $\mathrm{mg}^{-1}$ and $14.2 \mu \mathrm{M}$, respectively. SDS and Triton X-100 were found to inhibit the enzyme activity. The homology model of Aio showed correlation with the acidophilic adaptation of the enzyme. This is the first characterization studies of Aio from a species belonging to the Thiomonas genus. The arsenite oxidase was found to be among the acid-tolerant Aio reported to date and has the potential to
\end{abstract}

Electronic supplementary material The online version of this article (doi:10.1007/s13205-017-0740-7) contains supplementary material, which is available to authorized users.

Shafinaz Shahir

shafinazshahir@utm.my

Wei Kheng Teoh

wkteoh2@live.utm.my

Faezah Mohd Salleh

faezah@utm.my

1 Department of Biosciences and Health Sciences, Faculty of Biosciences and Medical Engineering, Universiti Teknologi Malaysia, 81310 Skudai, Johor, Malaysia be used for biosensor and bioremediation applications in acidic environments.

Keywords Acidic tolerance $\cdot$ Arsenite oxidase $\cdot$ Molecular modeling $\cdot$ Recombinant expression $\cdot$ Thiomonas delicata

\section{Introduction}

Arsenite oxidase catalyzes the oxidation of arsenite to arsenate by a two-electron transfer. Arsenite oxidase consists of two heterologous subunits; a large catalytic subunit (AioA) with bis-molybdopterin guanine dinucleotide (bisMGD) cofactor and a $3 \mathrm{Fe}-4 \mathrm{~S}$ iron sulfur cluster, and a small subunit (AioB) with Rieske $2 \mathrm{Fe}-2 \mathrm{~S}$ center. Arsenite oxidase is a member of the dimethylsulfoxide (DMSO) reductase family of molybdoenzyme which is a family of different prokaryotic redox enzymes that function in electron transport chain (Romão 2009).

Arsenite oxidizing bacteria have been isolated from diverse arsenic contaminated environments, such as cattledipping fluids, hot springs, mine tailing and drainage water. As an ancient bioenergetic enzyme which utilizes arsenite, a highly toxic metalloid as substrate, characterization of arsenite oxidase is of special interest for bioremediation and biosensor construction. To date, there are two extensively characterized arsenite oxidase which origin from a chemolithoautotrophic Alphaproteobacteria Rhizobium sp. NT-26 and heterotrophic Betaproteobacteria Alcaligenes faecalis. Both bacteria grow optimally at slightly alkaline $\mathrm{pH} \mathrm{8,} \mathrm{which} \mathrm{can} \mathrm{be} \mathrm{categorized} \mathrm{as} \mathrm{alkaline-tolerant}$ bacteria.

In mining environments, particularly acid mine drainage (AMD), inorganic As(III) are widespread as a result from the bioleaching of arsenic-bearing minerals. Under low $\mathrm{pH}$ 
condition, arsenite oxidizers from these extreme environment are commonly isolated with acid-tolerant properties with an optimum growth $\mathrm{pH}$ near neutrality with the exception of Thiomonas strains (Hallberg and Johnson 2003; Battaglia-Brunet et al. 2006; Katayama et al. 2006; Duquesne et al. 2008; Bryan et al. 2009; Arsène-Ploetze et al. 2010), that grow optimally around $\mathrm{pH}$ 5. Microbial metabolism in AMD causes natural attenuation process to occur whereby Thiomonas strains are suggested to have acted as the arsenite oxidizer (Casiot et al. 2003; Duquesne et al. 2003; Morin et al. 2003; Bruneel et al. 2006; Battaglia-Brunet et al. 2011; Bertin et al. 2011). Thiomonas strains are therefore essential for maintaining the arsenic biogeochemical cycle in AMD. Oxidation of As(III) plays a pivotal role in the natural bioremediation since it could contribute to an improved immobilization of arsenic in helping to mitigate arsenic contamination. Freel et al. (2015) showed that several phylogenetic groups of Thiomonas strains populated along Regious creek AMD for more than a decade even though in low abundance. Since the arsenic genomic islands are identified to have evolved differentially in the closely related Thiomonas strains, there are differences in the arsenite oxidation capability in the arsenic-rich environment (Freel et al. 2015).

Thiomonas delicata DSM 16361, isolated from Cheni gold mine, shows high arsenite oxidizing capability of $4 \mathrm{mg} \mathrm{As}(\mathrm{III}) \mathrm{l}^{-1} \mathrm{~h}^{-1}$ which grows optimally at $\mathrm{pH} 4-7$ as a moderate acidophile (Battaglia-Brunet et al. 2006). Most interestingly, purification and detailed characterization of Aio from facultative chemolithoautotrophic arsenite oxidizing Thiomonas strains have yet to be described. The characterization of the arsenite oxidase is of great importance as we could further explore the enzymatic features that contribute to the irreplaceable role of Thiomonas strains as an arsenite oxidizer in AMD. This could facilitate the engineering of enzymes and aid in construction of robust biosensor for monitoring arsenic in acid mining effluent. Therefore, in this study, by performing heterologous expression and purification of the arsenite oxidase from $T$. delicata, we characterized the arsenite oxidase in terms of its biochemical properties. Homology modeling of the enzyme was constructed to support the experimental findings. To the best of our knowledge, this is the first characterization study of arsenite oxidase from a chemolithoautotrophic betaproteobacterium.

\section{Materials and methods}

\section{Bacterial strains and growth conditions}

Thiomonas delicata DSM 16361 was obtained from German Collection of Microorganisms and Cell Cultures
(DSMZ) and grown in R2A medium (pH 7.2). Recombinant strains were grown aerobically at $37^{\circ} \mathrm{C}$ in LuriaBertani broth supplemented with $100 \mu \mathrm{g}$ ampicillin $\mathrm{ml}^{-1}$.

\section{Gene cloning and construction of the recombinant plasmid}

Genomic DNA was extracted by using Wizard Genomic DNA Purification kit (Promega). Based on the sequence of Thiomonas 3As arsenite oxidase gene (GenBank accession no. FP475956.1), oligonucleotide primers 5'-GGAGGCCATATGACCGAAAAAGTATCGCGTCGC-3' and $5^{\prime}$ GGAAAGCTTTCACGATTCAAACCCCGTACATGCG$3^{\prime}$ were designed to amplify the region of full length arsenite oxidase gene (aioBA) using Kapa HiFi Polymerase (Kapa Biosystem). With NdeI and HindIII restriction sites incorporated (underline), the amplified aioBA was cloned into pET21a (Novagen). According to Van Lis et al. (2012), a His-tag was introduced using PCR with forward primer using 5'-TAAGCCCATCACCGTCAGG- $3^{\prime}$ and reverse primer $5^{\prime}$-GTGGTGGTGGTGGTGGTGCAGCACGTTGGCCTGGCG-3' ${ }^{\prime}$ using as template the aioBApET21a construct. The construct aioBA-His-pET21a was then transformed into $E$. coli strain $\mathrm{C} 43$. The recombinant plasmid was confirmed by DNA sequencing. The sequence of the aioBA cloned from T. delicata DSM 16361 has been submitted to the GenBank database under the accession number of KX792110.

\section{Heterologous expression of $T$. delicata Aio in E. coli and purification of the recombinant enzyme}

The expression of recombinant Aio was performed in ZYM-5052 autoinduction medium (Studier 2005) including $100 \mu \mathrm{g}$ ampicillin $\mathrm{ml}^{-1}$ and $1 \mathrm{mM} \mathrm{Na}_{2} \mathrm{MoO}_{4}$ for $48 \mathrm{~h}$ in $20{ }^{\circ} \mathrm{C}$ at $180 \mathrm{rpm}$. Purification of Aio was performed from the total soluble fraction of recombinant $E$. coli cells. The cells were harvested and resuspended in cold binding buffer $\left(20 \mathrm{mM} \mathrm{NaH}{ }_{2} \mathrm{PO}_{4}, \mathrm{pH} 7.4,500 \mathrm{mM} \mathrm{NaCl}, 20 \mathrm{mM}\right.$ Imidazole) and lysed by using Qsonica Sonicator Q700 (amplitude 50\%, $1 \mathrm{~s}$ pulse on $1 \mathrm{~s}$ pulse off for $3 \mathrm{~min}$ ). Unlysed cells were removed by centrifugation at $10,000 \times g$ for $10 \mathrm{~min}$, and the lysate was subsequently ultracentrifuged at $110,000 \times g$ for $1 \mathrm{~h} 30 \mathrm{~min}$ to remove membrane fraction. The resulting supernatant was collected, filtered $(0.22 \mu \mathrm{m}$ filters, Merck Millipore) and then loaded onto HisTrap HP $1 \mathrm{ml}$ column (GE Healthcare), with flow rate set at $0.5 \mathrm{ml} \mathrm{min}{ }^{-1}$ for optimal protein loading. The column was equilibrated and washed with binding buffer with flow rate $1 \mathrm{ml} \mathrm{min}{ }^{-1}$ before eluted in elution buffer $\left(20 \mathrm{mM} \mathrm{NaH} \mathrm{PO}_{4}, \mathrm{pH} 7.4,500 \mathrm{mM} \mathrm{NaCl}\right.$, $500 \mathrm{mM}$ Imidazole) using imidazole gradient $(20-500 \mathrm{mM})$. The fraction containing active enzyme was 
pooled and dialyzed against $50 \mathrm{mM}$ MES buffer $\mathrm{pH}$ 5.5. The precipitated protein was then removed by centrifugation at $10,000 \times g$ for $5 \mathrm{~min}$. The supernatant was concentrated with Vivaspin 20 (MWCO 10,000 Da) centrifugal concentrator and loaded onto a HiLoad 16/60 Superdex 200 pre-equilibrated with $50 \mathrm{mM}$ MES buffer $\mathrm{pH} 5.5$, $150 \mathrm{mM} \mathrm{NaCl}$. Flow rate was set at $0.3 \mathrm{ml} \mathrm{min}^{-1}$. All chromatography steps were carried out at room temperature $\left(20-25{ }^{\circ} \mathrm{C}\right)$ using ÄKTAprime plus (GE Healthcare Life Sciences). Freshly purified enzyme was then concentrated for activity assay and SDS-PAGE was carried out according to method from Laemmli (1970).

\section{Enzyme assays}

Arsenite oxidase activity was assayed according to the method from Anderson et al. (1992) in 50 mM MES buffer (pH 5.5) with $60 \mu \mathrm{M}$ of an artificial electron acceptor 2,6dichlorophenolindophenol (DCPIP) and $200 \mu \mathrm{M}$ arsenite. Reduction of DCPIP was monitored spectrophotometrically at $600 \mathrm{~nm}$ at $25^{\circ} \mathrm{C}$ for $5 \mathrm{~min}(\varepsilon 600 \mathrm{pH} 5.5$ experimentally determined at $10 \mathrm{~mm}^{-1} \mathrm{~cm}^{-1}$ ) using 100 Vis Spectrophotometer (Buck Scientific). Protein concentration was determined by Bradford assay with bovine serum albumin as standard.

The kinetic study of the expressed enzyme was carried out using $0.5 \mu \mathrm{g} \mathrm{ml}^{-1}$ and varying concentrations of arsenite $(5-500 \mu \mathrm{M})$ in $50 \mathrm{mM}$ MES $\left(\mathrm{pH} \mathrm{5.5)}\right.$ at $25^{\circ} \mathrm{C}$, and the results were analyzed using Michaelis-Menten enzyme kinetic model using GraphPad Prism 7. One unit of Aio activity was defined as the amount of enzyme to oxidize $1 \mu \mathrm{mol}$ of arsenite per min under the assay conditions.

The effect of $\mathrm{pH}$ on Aio activity was investigated at $25^{\circ} \mathrm{C}$ in $50 \mathrm{mM}$ citrate-phosphate buffer ( $\left.\mathrm{pH} 2.5-4\right)$, MES buffer ( $\mathrm{pH}$ 5-6), sodium phosphate ( $\mathrm{pH} 7-8$ ) and glycine-

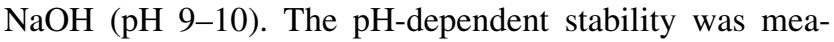
sured by incubating Aio $\left(0.03 \mathrm{mg} \mathrm{ml}^{-1}\right)$ in $50 \mathrm{mM}$ of buffer ( $\mathrm{pH} 2.5-10)$ for $16 \mathrm{~h}$ at $4{ }^{\circ} \mathrm{C}$ prior to measurement of the residual enzymatic activity. The effect of temperature on Aio activity was examined in $50 \mathrm{mM}$ MES (pH 5.5) between 25 and $70{ }^{\circ} \mathrm{C}$. Thermal stability was determined by measuring the residual activity after incubating Aio at temperatures between 25 and $70{ }^{\circ} \mathrm{C}$ after $1 \mathrm{~h}$.

The effect of different metal ions and chemical agents towards enzyme activity was investigated. The enzyme $\left(0.01 \mathrm{mg} \mathrm{ml}^{-1}\right)$ was assayed in the presence of $10 \mathrm{mM}$ metal ions $\left(\mathrm{K}^{+}, \mathrm{Li}^{+}, \mathrm{Ca}^{2+}, \mathrm{Co}^{2+}, \mathrm{Ni}^{2+}, \mathrm{Mn}^{2+}\right.$ and $\left.\mathrm{Zn}^{2+}\right)$ and anions $\left(\mathrm{NO}^{2-}, \mathrm{SO}_{4}{ }^{2-}\right.$ and $\left.\mathrm{Cl}^{-}\right)$. The effects of different surfactant concentrations (SDS and Triton X-100) and chemical reagents (EDTA and urea) on enzyme stability were examined with the additive in the reaction mixture for the assay. The enzyme activity without any additive was taken as $100 \%$.

\section{Statistical analysis}

All the experiments were conducted in triplicates measurements. The means were compared by ANOVA at 5\% significance level. The SPSS statistical package (IBM SPSS Statistics 23) was used for statistical evaluations.

\section{Bioinformatics analysis}

The homology model of arsenite oxidase from $T$. delicata was generated using the SWISS-MODEL workspace with arsenite oxidase crystal structure from A. faecalis (PDB: 1G8K chains A and B) as template. The Poisson-Boltzmann electrostatic potentials were calculated using the PDB2PQR and APBS. The structural superimposition and graphical representation of the structure model was prepared in UCSF CHIMERA software.

\section{Results and discussion}

\section{T. delicata arsenite oxidase gene cloning and analysis}

A total of $3093 \mathrm{bp}$ gene cluster comprising of both aioB and aioA was amplified successfully from genomic DNA of T. delicata DSM 16361. Nucleotide BLAST search of both $a i o B$ and aioA revealed high homology with Aio gene from a number of Thiomonas strains, with both genes sharing highest sequence identity of $99 \%$ to Thiomonas sp. CB2. Compared to previously characterized Aio, the deduced amino acid sequence of AioA (841 amino acid residues) display sequence identity of $65,63,62,45 \%$ from $\mathrm{Her}$ miniimonas arsenicoxydans, A. faecalis, Ralstonia sp. 22 and Rhizobium sp. NT-26, respectively. The deduced amino acid sequence AioB (179 amino acid residues) shared sequence identity of $61,58,56,41 \%$ from $A$. faecalis, Herminiimonas arsenicoxydans, Ralstonia sp. 22 and Rhizobium sp. NT-26, respectively.

\section{Expression of Aio in E. coli and purification of the recombinant enzyme}

Under the control of $\mathrm{T} 7$ promoter in plasmid pET-21a, the aioBA was expressed in E. coli $\mathrm{C} 43$ using autoinduction, where lactose acts as the inducer for protein expression. Recombinant proteins were purified by sequential Ni-NTA and gel filtration chromatographic steps. Purity of Aio was checked by the limit of electrophoresis and estimated to be $90 \%$ pure (Fig. 1). Similar to other arsenite oxidases (Ellis et al. 2001; Santini and vanden Hoven 2004; Duquesne et al. 2008; Prasad et al. 2009), the size of the large subunit arsenite oxidase (AioA) was around $91 \mathrm{kDa}$ while small 


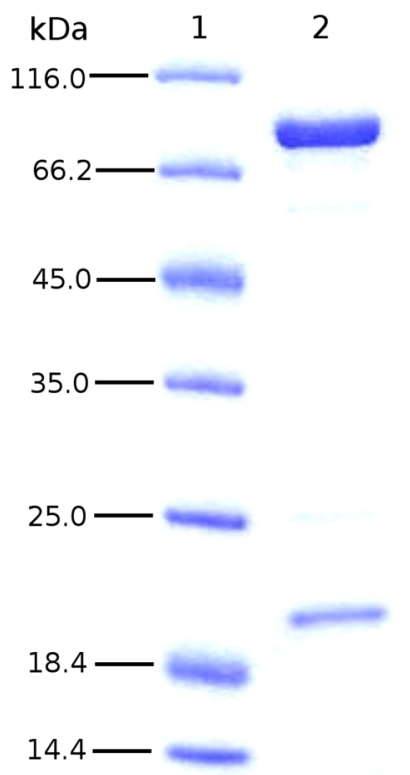

Fig. 1 SDS-PAGE gel of purified Aio stained with Coomassie Blue R350. Lane 1 Protein molecular weight marker; lane 2 T. delicata Aio

subunit (AioB) was $21 \mathrm{kDa}$ without removing the signal peptide.

\section{Characterization of recombinant Aio}

By utilizing DCPIP as the artificial electron acceptor, the recombinant Aio showed typical Michaelis-Menten kinetics with substrate arsenite, with $V_{\max }$ of $4 \pm 0.07 \mu$ mol arsenite oxidized $\min ^{-1} \mathrm{mg}^{-1}$ of proteins and $K_{\mathrm{m}} 14.2 \pm 1.03 \mu \mathrm{M}$ (Fig. 2). $K_{\mathrm{m}}$ of the recombinant Aio was found to be higher than Aio from A. faecalis, but lower than Arthrobacter sp. $15 \mathrm{~b}$ and NT-26 (Table 1). High $K_{\mathrm{m}}$ indicated the lower affinity of the arsenite oxidase towards arsenite substrate. As for the $V_{\max }$, the $T$. delicata Aio displayed a higher specific activity than the other arsenite oxidases.

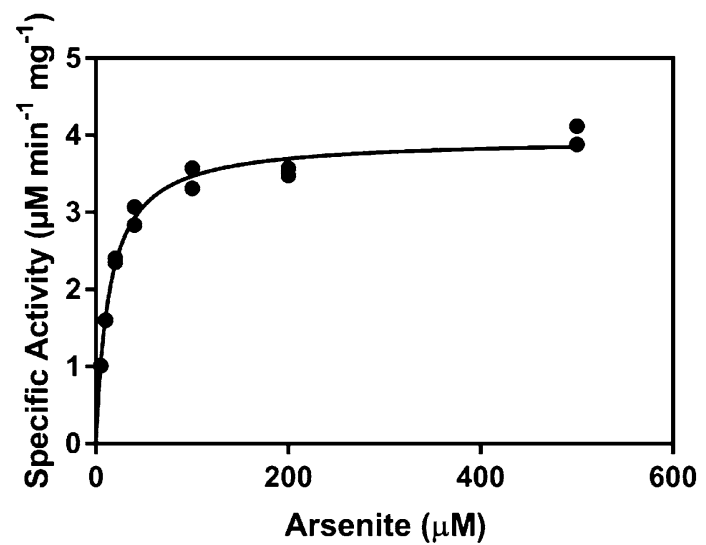

Fig. 2 Kinetic plot obtained with recombinant $T$. delicata Aio with substrate arsenite
The purified Aio displayed a typical bell-shaped $\mathrm{pH}-\mathrm{ac}-$ tivity relationship with maximum activity at $\mathrm{pH} 5.5$, which is the same as Aio NT-26 (Santini and vanden Hoven 2004) and $>80 \%$ relative activity between $\mathrm{pH} 5$ and 6 (Fig. 3a). However, after incubation for $16 \mathrm{~h}$ at $4{ }^{\circ} \mathrm{C}$, the $\mathrm{pH}$ stability profile was shifted where the enzyme retained high activity at $\mathrm{pH} 2.5-4$ and $>80 \%$ relative activity between $\mathrm{pH} 3$ and 6 . Beyond $\mathrm{pH} 7$, there was a drastic reduction in the enzyme activity. At $\mathrm{pH} 7-9$, the activity preserved was almost $60 \%$, while at pH 10, only $30 \%$ activity was retained (Fig. 3b). Since $T$. delicata has the ability to grow in wide $\mathrm{pH}$ range from $\mathrm{pH} 4$ to 7 , it is possible for Aio to develop acidstable properties to tolerate the $\mathrm{pH}$ fluctuation at the transition zones of acidic mine waters.

Optimum activity of Aio was found at $50{ }^{\circ} \mathrm{C}$, but statistically at par with $55^{\circ} \mathrm{C}$. Relatively high activity was noticeable at 40 and $55^{\circ} \mathrm{C}$ (Fig. 3c). Aio retained nearly $45 \%$ of its initial activity after incubation at $60{ }^{\circ} \mathrm{C}$ for $1 \mathrm{~h}$ (Fig. 3d). Even though there is a slight drop in the optimum temperature as compared with Aio from A. faecalis and NT-26 $\left(60^{\circ} \mathrm{C}\right)$, the Aio is still considered rather thermostable. These results showed that Aio is an acid-tolerant and thermostable enzyme.

Purified Aio was tested with a variety of cations, anions and chemical agents which might influence the enzyme activity. The selected metal ions and chemical agents showed no apparent inhibition to the Aio activity with more than $80 \%$ residual activity retained as shown in Table 2. Both $\mathrm{Co}^{2+}$ and $\mathrm{Zn}^{2+}$ did not exhibit obvious inhibition to Aio activity as to Arthrobacter sp. 15b Aio (Prasad et al. 2009). $\mathrm{Co}^{2+}$ and $\mathrm{Zn}^{2+}$ strongly inhibited Arthrobacter sp. 15b Aio where only 1.5 and $1.8 \%$ arsenite oxidation activity was retained after treatment (Prasad et al. 2009). By comparison, T. delicata Aio was tolerant to $\mathrm{Co}^{2+}$ and $\mathrm{Zn}^{2+}$, retaining 84 and $88 \%$ residual activity, respectively. This heavy metal tolerance of $T$. delicata Aio is possible, whereby genes conferring resistance to zinc and cobalt were found in the genome of Thiomonas sp. 3As (Arsène-Ploetze et al. 2010). The addition of $10 \mathrm{mM}$ sulphate anion $\left(\mathrm{SO}_{4}{ }^{2-}\right)$ did not inhibit $T$. delicata Aio as well. This ability to tolerate high sulphate anions might be explained by the presence of this anion in AMD formed via the oxidation of pyrite that could lead to an increased ability of T. delicata Aio to resist sulphate. Surfactant SDS and Triton X-100 were observed to inhibit the activity of Aio with residual activity of 60 and $19 \%$.

\section{Homology modeling analysis}

To explore the structural basis underlying the differences in enzymatic properties, a homology model was built using $A$. faecalis Aio crystal structure was used as a template by 
Table 1 Characteristic of $T$. delicata Aio compared with Aio from other mesophilic organisms

\begin{tabular}{llll}
\hline Source & $K_{\mathrm{m}}(\mu \mathrm{M})$ & $V_{\max }\left(\mathrm{U} \mathrm{mg}^{-1}\right)$ & References \\
\hline Thiomonas delicata & 14.2 & 4 & This study \\
Alcaligenes faecalis & 8 & 2.88 & Anderson et al. (1992) \\
Arthrobacter sp. 15b & 26 & 2.45 & Prasad et al. (2009) \\
Rhizobium sp. NT-26 & 61 & 2.4 & Santini and vanden Hoven (2004)
\end{tabular}

One unit of enzyme activity is defined as the amount of enzyme necessary to oxidize $1 \mu$ mol of arsenite per min using DCPIP as electron acceptor under the assay conditions
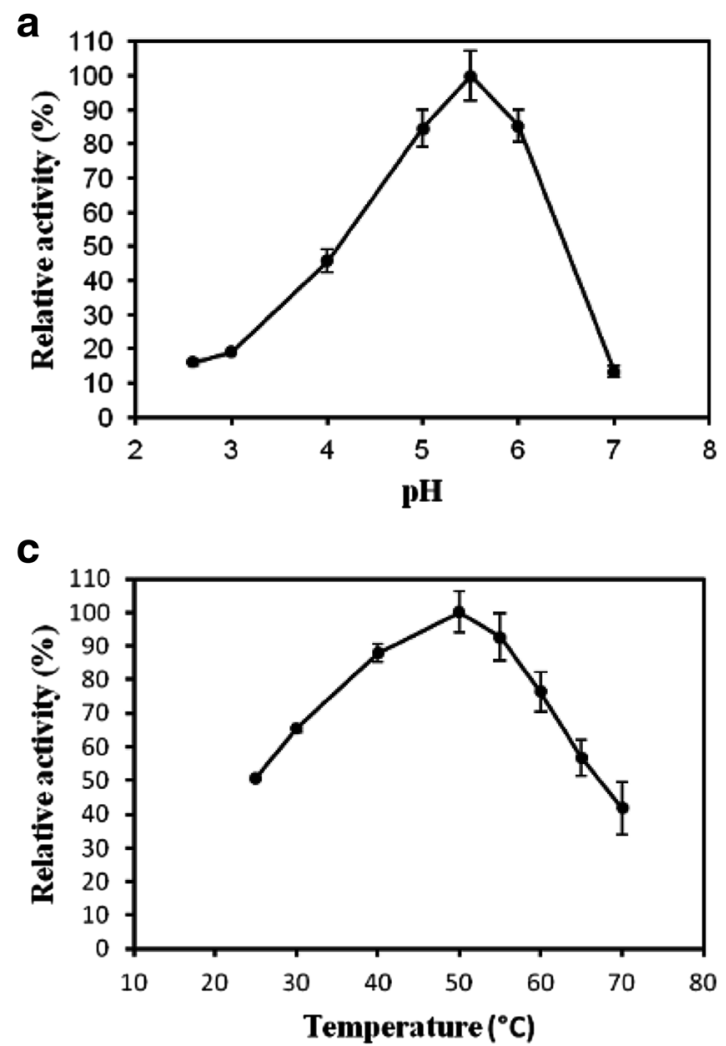

Fig. 3 Effects of $\mathrm{pH}$ and temperature on the activity of purified Aio. a $\mathrm{pH}$-activity profile; b $\mathrm{pH}$ stability relationship; c temperature activity dependence; $\mathbf{d}$ temperature stability profile. The effect of $\mathrm{pH}$ on Aio activity was investigated at $25^{\circ} \mathrm{C}$ in $50 \mathrm{mM}$ buffer $(\mathrm{pH}$ $2.5-7)$. The $100 \%$ relative activity was $3.1 \pm 0.2 \mu \mathrm{mol} \mathrm{min} \mathrm{mg}^{-1} \mathrm{mg}^{-1}$. $\mathrm{pH}$ stability studies were carried out by incubating enzymes $\left(0.03 \mathrm{mg} \mathrm{ml}^{-1}\right)$ in $50 \mathrm{mM}$ buffers $(\mathrm{pH} 2.5-10)$ at $4{ }^{\circ} \mathrm{C}$ for $16 \mathrm{~h}$ prior to measurement of residual activity. The $100 \%$ relative activity was

SWISS-MODEL. The reliability of the model was supported by its high sequence identity of $64 \%$ and with QMEAN4 score of -2.16 . Comparison of the homology model and template showed high similarity in overall fold as well as active site residues. Notable difference between the template and model was observed on the surfaces of the enzyme (Fig. 4). One of the distinct features of Aio is the existence of a 15-residue-longer loop near the catalytic cleft. The loop region is unique in all Thiomonas strain.
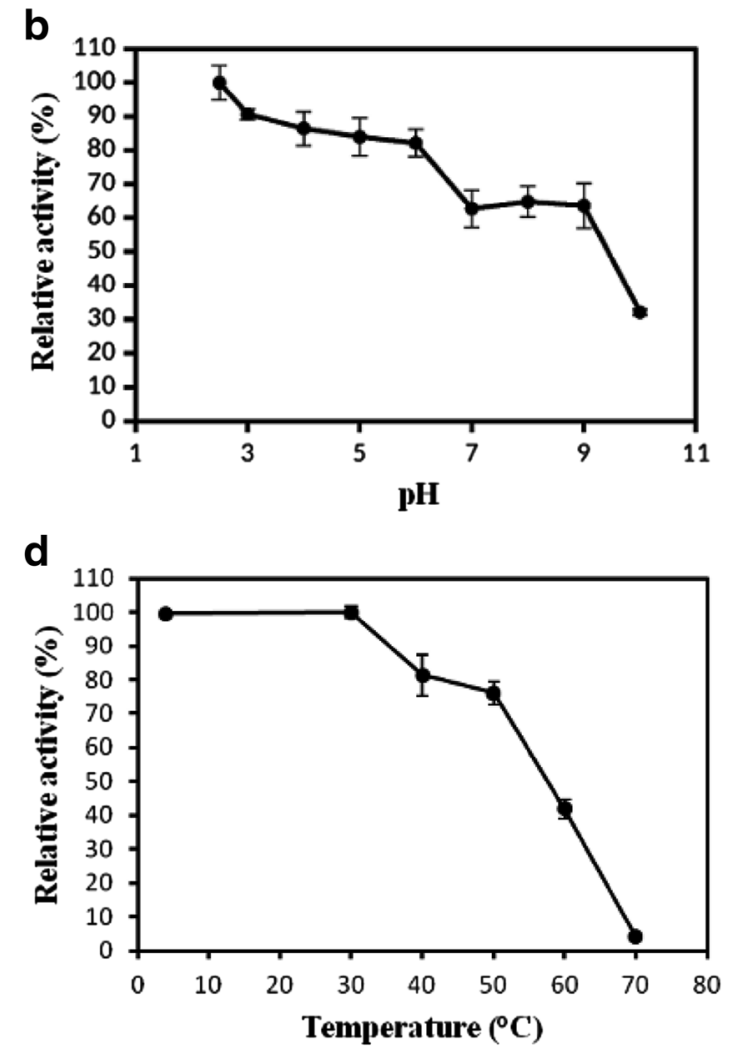

$3.5 \pm 0.3 \mu \mathrm{mol} \mathrm{min} \mathrm{mg}^{-1}$. The effect of temperature on Aio activity was examined in $50 \mathrm{mM}$ MES (pH 5.5) from 25 to $70{ }^{\circ} \mathrm{C}$. $100 \%$ relative activity was $3.4 \pm 0.2 \mu \mathrm{mol} \mathrm{min}{ }^{-1} \mathrm{mg}^{-1}$. The temperature-stability relationship was studied after incubation at different temperature $\left(10-70{ }^{\circ} \mathrm{C}\right)$ for $1 \mathrm{~h}$ in $50 \mathrm{mM}$ MES (pH 5.5). $100 \%$

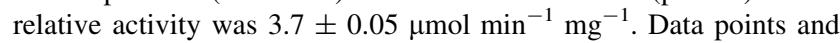
error bars represent mean and standard error of at least three assays, respectively, $p<0.05$

This could contribute to the difference in enzyme stability and flexibility, where the longer surface loop can lead to an increase of possible amplitude of the movement between the secondary structures.

In extreme environments, the nature of protein surfaces plays essential roles to maintain the protein stability. Located either at periplasm or membrane attached, Aio is likely to be exposed to $\mathrm{pH}$ of the extracellular environment. A study from Wilks and Slonczewski (2007) demonstrated 
Table 2 Effects of metal ions, anions and chemicals on arsenite oxidase activity

\begin{tabular}{lc}
\hline & Relative activity $(\%)$ \\
\hline Control & $100 \pm 5.1$ \\
Metal ions $(10 \mathrm{mM})$ & \\
$\mathrm{K}^{+}$ & $91.9 \pm 4.2$ \\
$\mathrm{Li}^{+}$ & $104.6 \pm 4.9$ \\
$\mathrm{Ca}^{2+}$ & $94.9 \pm 1.3$ \\
$\mathrm{Co}^{2+}$ & $83.8 \pm 7.5$ \\
$\mathrm{Ni}^{2+}$ & $89.9 \pm 7.4$ \\
$\mathrm{Mn}^{2+}$ & $101 \pm 1.8$ \\
$\mathrm{Zn}^{2+}$ & $87.8 \pm 3.4$ \\
$\mathrm{Anions}^{2-}$ & \\
$\mathrm{NO}^{2-}$ & $94.4 \pm 8.9$ \\
$\mathrm{SO}_{4}{ }^{2-}$ & $93.9 \pm 1.8$ \\
$\mathrm{Cl}$ & \\
$\mathrm{Chemicals}^{-}$ & $100.2 \pm 4.9$ \\
Urea $(10 \mathrm{mM})$ & \\
$\mathrm{EDTA}(10 \mathrm{mM})$ & $100.3 \pm 1.7$ \\
$\left.\mathrm{SDS}^{2} \mathrm{mM}\right)$ & $91.3 \pm 1.8$ \\
Triton X-100 (0.1\%, v/v) & $60.9 \pm 8.5$ \\
\hline
\end{tabular}

Values are represented by mean and standard error of at least three assays. $100 \%$ relative activity $=3.9 \pm 0.2 \mu \mathrm{mol} \mathrm{min}^{-1} \mathrm{mg}^{-1}$

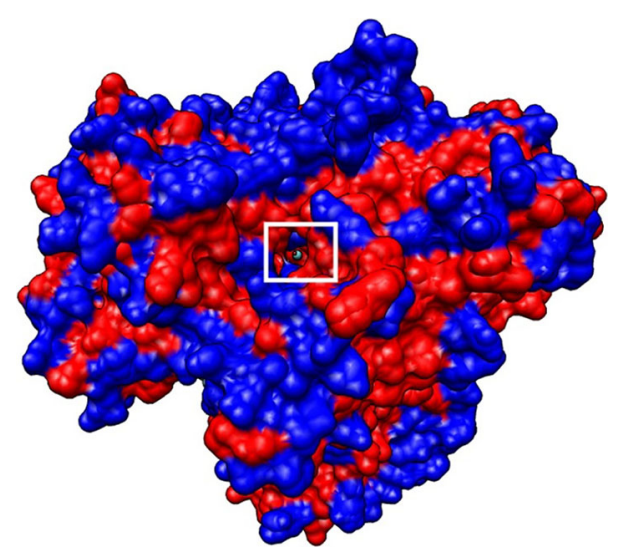

Fig. 4 Space-filling homology model of T. delicata Aio. Active site of the enzyme is boxed. Conserved residues between the $T$. delicata Aio and A. faecalis structure are red; different residues are blue

that the periplasm of gram negative bacteria do maintain the same proton concentration as the surrounding environment even though the cytoplasm is maintained at near neutral $\mathrm{pH}$. Therefore, by calculating the electrostatic potential data of the surfaces of Aio (Fig. 5), it was revealed that the surfaces of $T$. delicata Aio are rich with positively charge residues, while A. faecalis and NT-26 Aio have more negatively charged surface residues. This observation might contribute to the $\mathrm{pH}$ stability of $T$. delicata Aio, whereby penetration of hydronium ions inside a structure of predominantly basic protein surface can be
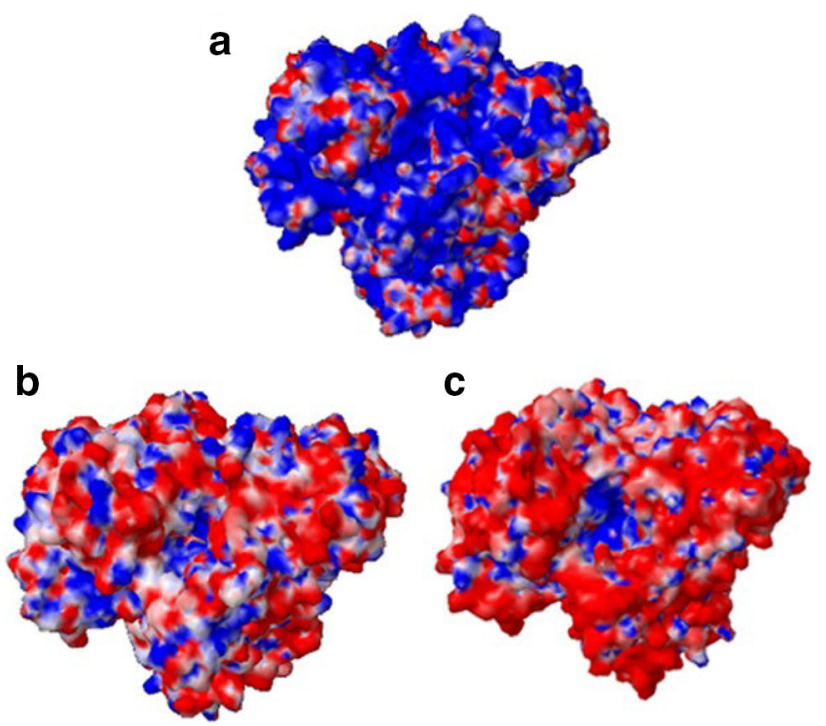

Fig. 5 Electrostatic rendering of the solvent-accessible surface of a $T$. delicata Aio, b A. faecalis $1 \mathrm{G} 8 \mathrm{~K}$ and $\mathbf{c}$ NT-26 4AAY. Computed at $\mathrm{pH} 7$ with $\mathrm{red}(-5 \mathrm{kT} / \mathrm{e})$ and blue $(5 \mathrm{kT} / \mathrm{e})$

avoided at low $\mathrm{pH}$ as shown in an acid-resistant citrate synthase (Francois et al. 2006).

\section{Conclusion}

The characterization of Aio from a species belonging to the Thiomonas genus was described for the first time. The high activity of T. delicata DSM 16361 Aio coupled with acidstable and metal tolerance properties suggests that the enzyme has potential to be used for biosensor and bioremediation applications in acidic environments.

Acknowledgements This work was supported by grant from Universiti Teknologi Malaysia GUP (Grant Number: 07H70) and MyBrain15 which is funded by Ministry of Higher Education Malaysia.

\section{Compliance with ethical standards}

Conflict of interest The authors declare that they have no conflict of interest.

\section{References}

Anderson GL, Williams J, Hille R (1992) The purification and characterization of arsenite oxidase from Alcaligenes faecalis, a molybdenum-containing hydroxylase. J Biol Chem 267:23674-23682

Arsène-Ploetze F, Koechler S, Marchal M et al (2010) Structure, function, and evolution of the Thiomonas spp. genome. PLoS Genet 6:e1000859. doi:10.1371/journal.pgen.1000859

Battaglia-Brunet F, Joulian C, Garrido F et al (2006) Oxidation of arsenite by Thiomonas strains and characterization of Thiomonas 
arsenivorans sp. nov. Antonie Van Leeuwenhoek 89:99-108. doi:10.1007/s10482-005-9013-2

Battaglia-Brunet F, El Achbouni H, Quemeneur M et al (2011) Proposal that the arsenite-oxidizing organisms Thiomonas cuprina and "Thiomonas arsenivorans" be reclassified as strains of Thiomonas delicata, and emended description of Thiomonas delicata. Int J Syst Evol Microbiol 61:2816-2821. doi:10.1099/ ijs.0.023408-0

Bertin PN, Heinrich-Salmeron A, Pelletier E et al (2011) Metabolic diversity among main microorganisms inside an arsenic-rich ecosystem revealed by meta- and proteo-genomics. ISME J 5:1735-1747. doi:10.1038/ismej.2011.51

Bruneel O, Duran R, Casiot C et al (2006) Diversity of microorganisms in Fe-As-rich acid mine drainage waters of Carnoulès, France. Appl Environ Microbiol 72:551-556. doi:10.1128/AEM. 72.1.551-556.2006

Bryan CG, Marchal M, Battaglia-Brunet F et al (2009) Carbon and arsenic metabolism in Thiomonas strains: differences revealed diverse adaptation processes. BMC Microbiol 9:127. doi:10. 1186/1471-2180-9-127

Casiot C, Morin G, Juillot F et al (2003) Bacterial immobilization and oxidation of arsenic in acid mine drainage (Carnoulès creek, France). Water Res 37:2929-2936. doi:10.1016/S00431354(03)00080-0

Duquesne K, Lebrun S, Casiot C et al (2003) Immobilization of arsenite and ferric iron by Acidithiobacillus ferrooxidans and its relevance to acid mine drainage immobilization of arsenite and ferric iron by Acidithiobacillus ferrooxidans and its relevance to acid mine drainage. Appl Environ Microbiol 69:6165-6173. doi:10.1128/AEM.69.10.6165

Duquesne K, Lieutaud A, Ratouchniak J et al (2008) Arsenite oxidation by a chemoautotrophic moderately acidophilic Thiomonas sp.: from the strain isolation to the gene study. Environ Microbiol 10:228-237. doi:10.1111/j.1462-2920.2007.01447.x

Ellis PJ, Conrads T, Hille R, Kuhn P (2001) Crystal structure of the $100 \mathrm{kDa}$ arsenite oxidase from Alcaligenes faecalis in two crystal forms at 1.64 and $2.03 \AA$. Structure 9:125-132

Francois JA, Starks CM, Sivanuntakorn S et al (2006) Structure of a NADH-insensitive hexameric citrate synthase that resists acid inactivation. Biochemistry 45:13487-13499. doi:10.1021/ bi061083k
Freel KC, Krueger MC, Farasin J et al (2015) Adaptation in toxic environments: arsenic genomic islands in the bacterial genus Thiomonas. PLoS One 10:1-20. doi:10.1371/journal.pone. 0139011

Hallberg KB, Johnson DB (2003) Novel acidophiles isolated from moderately acidic mine drainage waters. Hydrometallurgy 71:139-148. doi:10.1016/S0304-386X(03)00150-6

Katayama Y, Uchino Y, Wood AP, Kelly DP (2006) Confirmation of Thiomonas delicata (formerly Thiobacillus delicatus) as a distinct species of the genus Thiomonas Moreira and Amils 1997 with comments on some species currently assigned to the genus. Int $\mathbf{J}$ Syst Evol Microbiol 56:2553-2557. doi:10.1099/ijs.0.64299-0

Laemmli UK (1970) Cleavage of structural proteins during the assembly of the head of bacteriophage T4. Nature 227:680-685

Morin G, Juillot F, Casiot C et al (2003) Bacterial formation of tooeleite and mixed arsenic(III) or arsenic(V)-Iron(III) gels in the Carnoulès Acid mine drainage, France. A XANES, XRD, and SEM study. Environ Sci Technol 37:1705-1712. doi:10. 1021/es025688p

Prasad KS, Subramanian V, Paul J (2009) Purification and characterization of arsenite oxidase from Arthrobacter sp. Biometals 22:711-721. doi:10.1007/s10534-009-9215-6

Romão MJ (2009) Molybdenum and tungsten enzymes: a crystallographic and mechanistic overview. Dalt Trans. doi:10.1039/ B821108F

Santini JM, vanden Hoven RN (2004) Molybdenum-containing arsenite oxidase of the chemolithoautotrophic arsenite oxidizer NT-26. J Bacteriol 186:1614-1619. doi:10.1128/jb.186.6.16141619.2004

Studier FW (2005) Protein production by auto-induction in highdensity shaking cultures. Protein Expr Purif 41:207-234. doi:10. 1016/j.pep.2005.01.016

Van Lis R, Nitschke W, Warelow TP et al (2012) Heterologously expressed arsenite oxidase: a system to study biogenesis and structure/function relationships of the enzyme family. Biochim Biophys Acta Bioenergy 1817:1701-1708. doi:10.1016/j.bbabio. 2012.06.001

Wilks JC, Slonczewski JL (2007) pH of the cytoplasm and periplasm of Escherichia coli: rapid measurement by green fluorescent protein fluorimetry. J Bacteriol 189:5601-5607. doi:10.1128/JB. 00615-07 